\title{
ESTIMATION OF DEMAND SYSTEM IN AN AIDS MODEL: THE OPPORTUNITY FOR EXPORTING THAI AGRICULTURAL PRODUCTS
}

\author{
WARIPAS JIUMPANYARACH \\ Chulalongkorn University, Thailand
}

\section{ABSTRACT}

This paper reports the results of the estimation of Almost Ideal Demand System (AIDS) model is developed to estimate quantity respond based on price. Five major export agricultural products data from the office of Agricultural Economics, Thailand and Biofuel policy from the office of the National Economic and Social Development Broad were used. The AIDS model estimates demand of palm, cassava, and sugar are highly response to changed price. Rubber and rice has less response to the changed price. All of major agricultural products are affect expenditure of Thailand export. This result suggest that the opportunity for increasing supply of energy plants, which benefits to Thai farmer communities for expanding market share in energy plants in domestic and global market.

\section{JEL CLASSIFICATION \& KEYWORDS}

- Q13 = Agricultural products a Almost ideal demand system (AIDS)

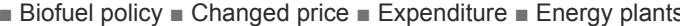

\section{INTRODUCTION}

Thailand is one of the agricultural countries that have major gross domestic product (GDP) from Agricultural products. Major of the agricultural products are palm, rubber, cassava, rice, and sugar. There are several competitive countries which can produce and import as same as Thailand. Price and income is the most important indicators for demand and supply on the global market of agricultural product.

A major influence factor is a price of the agricultural products which indicate demand and supply of agricultural market in Thailand and global. Price limits productions and value import and export of agricultural products also GDP of the country especially agricultural countries. Government uses this to establish nation policies related agriculture for example energy policy such as renewable energy and substitution energy. The policy encourages people to use substituted or renewable energy. Agricultural products such as palm, cassava, rice, and sugar become major products; can produce biofuel energy. Demand for the products has increased since policy was used. Not only Thailand but also worldwide. Also, climate change is a major factor that decline agricultural products while the demand for food in the global is increasing. Many countries could not produce food as much as they need. Import food and other commodities are increasing. This is an opportunity of agricultural countries to increase production to supply the demand of the global market, support the countries' economy, and increase levels of life quality in the agricultural society.

Rangkakulnuwat (2008) studied eight agricultural export agricultural products of Thailand using Linear Almost Ideal Demand System (LAIDS). The results showed that Thailand export rice and maize as luxury which rubber and fresh and frozen ducks and chicken are necessary. Fresh and frozen and coffee are inferior.

The demand of agricultural products especially food demand in neighbor countries are based on expenditure and price. The two factors indicate trend of food consumption. Le (2008) studied Vietnam demand for food consumption by using a linear approximate of Almost Ideal Demand System
(AIDS) model and extended AIDS model using the Vietnam Living Standard Survey (VLSS) in 2004. Food consumption in Vietnam purchased rice, fruit, meat-fish increased less than their prices increased but they purchased more when small price of non-food increases.

Also, the study showed that income and price increase consumption of non-rice food more than rice-food, meat, and fish the demand for food in Vietnam while age, gender, and education did not affect.

Similarly, Sheng et. al. (2008) studied food consumption pattern in Malaysia. They used the Linear Approximate/ Almost Ideal Demand System (LA/AIDS) model to estimate the demand. The results showed that food consumption relied on income. Sheng et. al (2008) found that income increased the food consumption of the countries. The demand for meat, fruit, vegetable, sugar, and beverage and other food are elastic. The wealthy Malaysia consumer increased purchasing in all food products.

Due to an agricultural managing process, most of agricultural countries cannot expect the production. There are not many technologies support the production also marketing system. Balancing between demand and supply of agricultural products in own countries and exporting products to other countries are necessary. Demand consumption is studied to be information for managing agricultural commodities.

Almost Ideal Demand Systems (AIDS) model is useful in term of analysis in different types of market demand systems. For example, the structure change of meat demand, this model is used to predetermined and quantities endogenous price estimation. The demand is estimated for supply side that relates to own price elasticity and income elasticity (Sakong and Haye, 1993). Another example is still on meat demand. The income distribution affects aggregated meat demand. The reflection of model is on changing of expenditure. The expenditure elasticity is calculated for the structure change in the market. Again, AIDS model is used for testing of hypothesis between different products between meat and chicken in term of consumer preferences. It is based on price and demand (Eales and Unnevehr, 1988).

This study aims to estimate demand for agricultural products which are palm, rubber, cassava, rice, and sugar in Thailand using the Office of Agricultural Economics Survey. Almost Ideal Demand System (AIDS) is used to analyze the demand system of agricultural products. The model uses Ordinary Least Squares (OLS) investigates the consumption demand based on price of the commodities. The estimations provide own-price elasticity and cross-price elasticity for agricultural commodities and expenditure commodities.

This paper is organized as follow: Section II presents an econometric model provides information to support three hypotheses. First is price of agricultural products affect export demand in Thailand. Also, this model shows decision making of global market respond to different agricultural products. The elasticity of market demand of different types of products is analyzed. The second hypothesis is policy of agricultural products of Thailand affects the demand related

33 
price in the world, substituted energy policies are added to dummy variables. Finally, climate change increase opportunities of developing countries become a major value in the agricultural market.

Section III provides the data in this study were collected from 1998-2010. Section IV shows the results from the estimated AIDS model. Section $\mathrm{V}$ is a discussion. Finally, section VI is the conclusion.

\section{Methodology}

Expenditure and price are major factors for estimating consumer demand and supply in several models. The models are proposed to answer a behavior of consumers purchasing. Engel curve model explained the demand of purchasing depend on income. A study of demand of agricultural products in the global market becomes interested. Also, time series model has been used. Finally, an Almost Ideal Demand System (AIDS) model has been developed by Deaton and Muellbauer. This model explains effects of price to consumer demand during time period.

The study of market demand due to the price in market systems is necessary. Almost Ideal Demand System Model or AIDS Model is used to estimate price elastic demand for the products in the market. This model estimates the demand system in market, which involves the axioms of choice exactly, that is consistent with the aggregation of micro model demand in the market (Eales and Unnevehr, 1988). The estimation is based on the restriction of homogeneity and Slutsky Symmetric through linear restriction on fixed parameters (Deaton and Muellbauer, 1988).

The demand equations are set on arbitrary first order approximation and second order approximation to any arbitrary direct and indirect utility function or cost function. The market demand provides the outcome from rational representative consumers. The preferences minimize cost or expenditure function at given price of the utility level (Deaton and Muellbauer, 1980). The AIDS model is useful in term of price elasticity in the demand market. The demand function of AIDS model is set in the budget share form, which is (Deaton and Muellbauer. 1980; Eales and Unnevehr, 1988):

$$
w_{i}=\alpha_{1}+\sum_{i} \gamma_{i j} \log p_{j}+\beta_{i} \log \left(\frac{x}{p}\right)
$$

where $w_{i}=$ expenditure share of commodity $i^{\text {th }}, p i=$ price of commodity $i^{\text {th }}, \alpha_{i}, \gamma_{i j}, \beta_{i}$ are parameters.

The model of cost function derives from utility maximized behavior that holds demand of budget and price.

$\log P=\alpha_{0}+\sum_{i=1}^{n} \alpha_{k} \log p_{k}+\frac{1}{2} \sum_{i=1}^{n} \sum_{i=1}^{n}{ }^{\gamma_{k j}} \log p_{k} \log p_{j}$

Price estimates in this model is nonlinear thus, the estimation model used the index known as Stone's price index $\left(\mathrm{P}^{*}\right)$. Stone's price index $\left(\mathrm{p}^{*}\right)$ is introduced to solve price problem (Alston and Foster and Green, 1994).

$$
\ln P^{*}=\sum_{j}^{n} w_{k t} \ln p_{k t}
$$

But Stone price index does not support the AIDS models. Finally, the correction of Stone Price index is (Moschini, 1995) then we used Paasche index (Moschini,1995) for this analysis.

$$
\ln P^{*}=\sum_{j}^{n} w_{k t} \ln \left(p_{i t} / p_{0 i}\right)
$$

According to homogeneity, it explains the relationship between prices or income changing while the budget share is still the same. This condition is hold within equation www.journals.cz/ constraint. The parameters of individual model are added to zero. Also, homogeneity in AIDS model will hold when budget share of each product change at the same time, this condition will add total of budget share equal to 1 . The model of this condition brings to adding up condition of AIDS model. This model is hold when adding up cross equation constraints (Barten, 1977).

$$
\sum \alpha_{1}=1 \quad \sum \sum \gamma_{i j}=0 \quad \sum \beta_{i}=0 \quad \sum \gamma_{i j}=0
$$

Next, symmetry hold in cross equation constraints, which depend upon the substitution effect compensated price demand. The condition involves Hicksian substitution matrix. The condition is relative to change quantity of own product when cross price change. The substitution matrix is from function:

$$
\gamma_{i j}=\gamma_{j i}
$$

As we know, the model usually uses for price elasticity and income elasticity under Mashallian price elasticity that is related to income elasticity by homogeneity and symmetry condition (Moschini, 1995). The model predicts uncompensated elasticity and compensated elasticity. The accuracy is usually on compensated demand because of income effect. The effect involves the Stone's price index (Alston and Foster and Green, 1994). Thus, own price elasticity and cross price elasticity is measured by

$$
\begin{aligned}
\varepsilon_{i j}^{M} & =\frac{\gamma_{i j}}{w_{i}}-\beta_{i} \frac{w_{j}}{w_{j}}-\theta_{i j} \\
\varepsilon_{i j}^{H} & =\frac{\gamma_{i j}}{w_{i}}-\beta_{i} w_{j}-\theta_{i j}
\end{aligned}
$$

where $\theta_{i j}=1$ if $i=j$ and $\theta_{i j}=0$ if $i \neq j$.

According to expenditure elasticity from Ealse and etc. is measured by

$$
\varepsilon_{i}=1+\frac{\beta_{i}}{w_{i}}
$$

where $\varepsilon_{l}=$ expenditure elasticity.

The analyses for demand of different types of agricultural products use ordinary Least Squares (OLS) estimation. There are some relationships between total expenditure, and budget share based on AIDS model, which determines the level of utility at given prices. The hypothesis of this study investigates the relationship between demand for agricultural commodities export and their prices. Price effects are influence the demand when the country support biofuel policy and climate change in Thailand and neighbor countries.

\section{Data}

In this study, the data was conducted from the office of Agricultural Economics, Ministry of Agricultural and Cooperative, Thailand. The date are monthly from $1998-$ 2010. The government policy from the office of National Economic and Social Development Broad is used as dummy variable in the year that has policy supported sustainable energy produced by agricultural products during year 2002-2010. Also, climate change is use as dummy variable during year $2000-2010$.

Agricultural commodities in this study are quantity export and price of palm, rubber, cassava, rice, and sugar are shown during 1998-2010. Descriptive statistic shows in table 1. The average share of palm in total commodities is 0.12 percent, rubber is 27.39 percent, cassava is 2.25 percent, rice is 65.47 percent, and sugar are 4.73 percent.

\section{Results}

The AIDS equations were used to estimate the parameters of demand system for economic agricultural products of 
Thailand. Hence Thai bio-energy policy and climate change within the agricultural products of Thailand. The policy and phenomena affect both Thailand and global agricultural market. Choices and preferences within major Thai agricultural products are assumed to be independent of price change for other goods. Homogeneity and symmetric restrictions were imposed in accordance with the theoretical properties of demand systems. Also, the model is held the adding-up condition by restrictions. The system estimates in two stages using OLS.

Table 1 explains descriptive statistic of palm, rubber, cassava, rice, and sugar, which are major agricultural products of Thailand. From the above, rice has the most value of export share among other commodities. The major of Thai exporting always rice thus agricultural education, new developed technology and agricultural extension for rice should be developed. To support GDP of Thailand, other commodities still need policies to increase the productions for the international market and exporting commodities.

\begin{tabular}{|l|l|l|l|l|}
\hline \multicolumn{5}{|l|}{ Table 1: Descriptive statistic of variables } \\
\hline Variable & Mean & $\begin{array}{l}\text { Standard } \\
\text { Deviation }\end{array}$ & Maximum & Minimum \\
\hline Palm & 0,0012378 & 0,000000177 & 0,0099668 & 0,001601 \\
\hline Rubber & 0,2739473 & 0,0831881 & 0,6157715 & 0,1134997 \\
\hline Cassava & 0,0227408 & 0,000031072 & 0,0902592 & 0,014592 \\
\hline Rice & 0,6547306 & 0,2741081 & 0,8942224 & 0,1259134 \\
\hline Sugar & 0,0473435 & 0,00000351 & 0,3791999 & 0,0616172 \\
\hline
\end{tabular}

Source: Estimated from an Almost Ideal Demand System (AIDS) model, data from the office of Agricultural Economics, Ministry of Agricultural and Cooperative, Thailand, $1998-2010$.

The estimation results for AIDS model, equation 1 are shown in table 2. This estimation satisfies adding-up, homogeneity, and symmetry hypothesis. Government policies support substituted agriculture production (biofuel) is used to be a dummy variable also climate change.

The model estimate price coefficient by the AIDS model and reports the coefficient at 5 percent and 10 percent significant level. Thailand has major agricultural products which are palm, rubber, cassava, rice, and sugar. The export demand influences price, production, and income of the country. The supported government policy for exporting agricultural products are determined by using AIDS model presented in equation (1). The results are presented in table 2 . Table 2 presents coefficient in market share of palm, rubber, cassava, rice, and sugar, which are a major exports of Thailand to the world market. The dependent variables are share of major agricultural products and total expenditures.

Hence the equations systems are tested homogeneity for palm are statistically significant are 5 and 10 level. Indicating parameter relating to palm and rubber, cassava, rice, income, substituted energy policy, and climate change are statistically significant at the $5 \%$ level, which sugar, energy policy, and climate are negative impact. Rubber parameter is insignificant except cassava has negative impact and significant at $10 \%$ level. The parameter relating to cassava is negative statistically significant at $5 \%$ level with palm, and income. Rubber relates to cassava negative coefficient and statistically significant at $10 \%$ level. Rice relationship has income is statistically significant at $10 \%$ level. Final result shows that the parameter of palm relates to cassava, income, and substituted energy policy influence statistically significant with sugar at $10 \%$ level.

To calculate compensated and uncompensated elasticity by using the AIDS model and explained by Marshallian demand presented in table 3 . The own-price elasticity are responds of consumers to products of the commodities when price of another commodities have changed. These results are consistent with the own-price elasticity demand of the agricultural products has positive signs for rubber and rice, indicating the relationship between and price quantity follows the same direction. Palm, cassava, and sugar are negative, indicating the expected inverse relationship between price and quantity demand. As the results, the major expected agricultural products of Thailand, which are rubber, rice are small response to price change. Price limits change of quantity demand in the market as expected rubber and rice for normal goods. On the Opposite own price elasticity coefficient of palm, cassava, and sugar are expected for

\begin{tabular}{|c|c|c|c|c|c|c|}
\hline & Palm & Rubber & Cassava & & Rice & Sugar \\
\hline \multirow[t]{2}{*}{ Intercept } & $-0.00783^{* *}$ & 3,569637 & 0,306149 & & $-3,66687$ & 0,798919 \\
\hline & $(0.008998)$ & $(0.431206)$ & $(0.053288)$ & & $(0.463179)$ & $(0.340092)$ \\
\hline \multirow[t]{2}{*}{ Palm } & $-0.00139^{* *}$ & $-0,04736$ & $-0.00720^{* *}$ & & 0,096638 & $-0.04069^{*}$ \\
\hline & $(0.000436)$ & $(0.020891)$ & $(0.002582)$ & & $(0.022440)$ & $(0.016476)$ \\
\hline \multirow[t]{2}{*}{ Rubber } & $0.001758^{* *}$ & 0,181905 & $0.009550^{* *}$ & & $-0,16952$ & $-0,0237$ \\
\hline & $(0.000574)$ & $(0.027527)$ & $(0.003402)$ & & $(0.029568)$ & $(0.021710)$ \\
\hline \multirow[t]{2}{*}{ Cassava } & $0.000023^{* *}$ & $-0.01515^{*}$ & $-0.00556^{* *}$ & & $0.008641^{*}$ & $0.012044^{*}$ \\
\hline & $(0.000207)$ & $(0.009911)$ & $(0.001225)$ & $0.003499^{* *}$ & $(0.010646)$ & $(0.007817)$ \\
\hline \multirow[t]{2}{*}{ Rice } & $0.001120^{* *}$ & $-0,18498$ & $(0.004481)$ & & 0,143458 & 0,036907 \\
\hline & $(0.000757)$ & $(0.036257)$ & $0.011619^{* *}$ & & $(0.038946)$ & $(0.028596)$ \\
\hline \multirow[t]{2}{*}{ Sugar } & $-0.00172^{\star *}$ & $-0,00171$ & $(0.003632)$ & & 0,020888 & $-0,02907$ \\
\hline & $(0.000613)$ & $(0.029391)$ & $-0.00919^{\star *}$ & & $(0.031570)$ & $(0.023180)$ \\
\hline \multirow[t]{2}{*}{ Income } & $0.000234^{* *}$ & $-0,14281$ & $(0.001903)$ & & $0.185490^{*}$ & $-0.03373^{*}$ \\
\hline & $(0.000321)$ & (0.015396) & $0.017277^{* *}$ & & $(0.016538)$ & $(0.012143)$ \\
\hline \multirow[t]{2}{*}{ Policy } & $-0.00036^{\star *}$ & 0,076724 & $(0.002615)$ & & $-0,0915$ & $-0.00214^{*}$ \\
\hline & $(0.000442)$ & $(0.021159)$ & $0.014392^{* *}$ & & $(0.022728)$ & $(0.016688)$ \\
\hline \multirow[t]{2}{*}{ Climate Change } & $-0.00027^{* *}$ & 0,101162 & $(0.003409)$ & & $-0,11804$ & 0,002749 \\
\hline & $(0.000536)$ & $(0.025454)$ & & & $(0.027366)$ & $(0.02040)$ \\
\hline \multicolumn{7}{|c|}{${ }^{* \star}$ Denotes significance at $5 \%$ level } \\
\hline
\end{tabular}


luxury goods in absolute value. Quantity demand of palm, cassava, and sugar results are highly response to price change. These imply farmers should be more productive to receive some better benefits from the market demand.

The most accurate picture of cross-price elasticity substitution is either positive or negative, which provide a measuring of cross-price substitution effect. Positive crossprice substitution coefficients imply that is net substitution among palm rubber, and rice. Cassava, rubber, rice, and sugar are positive net substitution while negative is notable exception. Indicating economic crops, both food and energy are related. Prices of agricultural products change farmers' attitude for their agricultural products.

\begin{tabular}{|l|l|l|l|l|l|}
\hline \multicolumn{6}{|l|}{ Table 3: Elasticity } \\
\hline & Palm & Rubber & Cassava & Rice & Sugar \\
\hline Palm & $-2,10761$ & 0,062119 & $-1,18499$ & 0,10103 & $-1,58754$ \\
\hline Rubber & $-0,19606$ & 0,062119 & $-0,02755$ & $-0,44446$ & $-0,094051$ \\
\hline Cassava & $-0,38027$ & 1,30706 & $-1,18499$ & 0,31851 & 0,23926 \\
\hline Rice & 0,16104 & $-0,040466$ & 0,034026 & 0,10103 & 0,14725 \\
\hline Sugar & $-0,86178$ & $-0,4704$ & 0,26002 & 0,98381 & $-1,58754$ \\
\hline
\end{tabular}

Source: Estimated from an Almost Ideal Demand System (AIDS) model, data from the office of Agricultural Economics, Ministry of Agricultural and Cooperative, Thailand, $1998-2010$.

The expenditures on palm and rice are increasing as their prices increase while expenditures on rubber, cassava, and sugar are increasing as their prices decrease. The expenditure is smaller than percentage change in price, if other things are constant. These results are consistent with the own-price inelasticity demand of the agricultural products.

The results imply that expenditure elasticity is explained as a change of commodity demand response income growth in table 4. These indicate that expenditure elasticity of palm and rice are positive. Total export valued of the country increases as demand of palm and rice increases while the others are negative relationship.

\begin{tabular}{|l|l|}
\hline Table 4: Expenditure elasticity \\
\hline Type of Expenditure & Elasticity \\
\hline Palm & 1,17436 \\
\hline Rubber & $-112,125$ \\
\hline Cassava & $-5,68259$ \\
\hline Rice & 148,332 \\
\hline Sugar & $-26,6989$ \\
\hline
\end{tabular}

Source: Estimated from an Almost Ideal Demand System (AIDS) model, data from the office of Agricultural Economics, Ministry of Agricultural and Cooperative, Thailand, $1998-2010$.

Figure 1 explains price of agricultural products, which are palm, rubber, cassava, rice, and sugar. Price of rice are fluctuated than other products, is these other variable are constant. Comparing price among these products indicate that price is increasing during the observed period. Prices of major agricultural products of Thailand depend upon market mechanism and other domestic and global factors. Not only demand and supply for the products but politics and world phenomena are influence.

FAO reported in year 1997 and 2007, the quantity export of rice in all countries are not different. It was possible depends upon the climate change and policy. Also exported value of rubber, Thailand has increased valued exported and become highest share in the world market since 2005(FAO, Agricultural products 1997-2007).

Again, China has the most exporting energy plants, which relates the government policy to support a substituted www.journals.czl

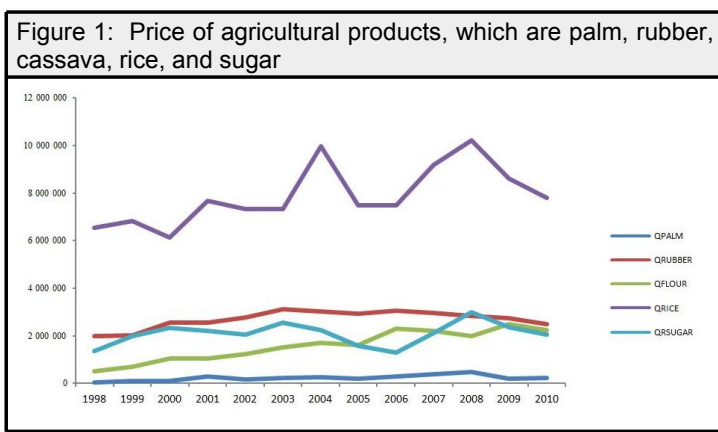

Source: The office of Agricultural Economics, Ministry of Agricultural and Cooperative, Thailand, 1998-2010.

energy also becoming top major agricultural products of Thailand; most countries in Asia produce sugar as important exported agricultural products. Thus, Thailand has shared with other in the world market, price and production depends upon the demand of the international market (FAO, Agricultural products 1997-2007).

\section{Discussion}

Obviously, price of agricultural products are moving as a cycle. This depends upon food demand, energy policy, and disaster. The study reveals some factors that influence agricultural market. Increasing cost of production, bio-energy policy, and disaster has changed the demand and supply in the market. New policies are established to support the agricultural market especially developing countries. Perhaps, this is an opportunity to the countries in order to increase GDP and increase quality of life.

Thailand is well known as agricultural country. Major GDP is from agricultural product. The agricultural products are produced to support the food demand of the country and raw material in the global. The demands for agricultural products influence GDP of Thailand. Rice, rubber, cassava, and sugar make Thailand become a major export market while palm in Thailand is enough for consuming in Thailand. In present, the government support palm production because palm is used in bio-energy ingredient. Thailand expects to export more and import less for palm products.

Thailand has this opportunity increasing market share in a global market. This research focused on palm, rubber, cassava, rice, and sugar, which impacted on food and bio-energy market. Demand and supply of palm, rubber, cassava, and sugar impacted on bio-energy market while rice impacts on food market. For example, price of rice is increasing during 2007-2009 because of cost of production and demand in the market (Pacific food system outlook, 2009-2010), then price decline. As this result, price of the agricultural commodities usually raise and declined during the period of time.

The objective of this study is to estimate the demand for palm, rubber, cassava, rice, and sugar in the global market related to their price. Also, nation policy and disaster affect the demand of agricultural commodities in domestic and international. Elasticity explains a relationship between price and demand in the domestic and international. The results suggested the absolute own-price elasticity for rubber and rice is small price response while others are highly response to changed price. Considering, rubber and rice shows the price of production increases, the valued of export still increases. Rubber is a raw material in lot of industries such as wheel also rice is a major demand for food market thus the demand of these products is not affected from their price. These studies show that price of these products are 
influence the exporting of Thailand. Concluding, Demand for energy plants is highly response with price, rubber and rice are economic agricultural products of Thailand and necessary for live rather than energy purpose.

Another result suggests palm and rice were positive expenditure elastic. Rice has quantity demand very sensitive to consumer expenditure. Small change of rice export large impacts on the budget share in the market in same direction. In opposite, Rubber, cassava, and sugar have negative expenditure elastic. Quantity demand for rubber is the most sensitive to the consumer expenditure.

This study revealed that price of palm cassava, and sugar induces the quantity demand for the export because of they are necessary exporting products of the country. Small change of price had large impact quantity demand. Palm cassava, and sugar are important in the agricultural market also were major export products for bio-energy and food, which price affects the demand. If there are strong policy support these products, GDP of the country will increase permanently. Bioenergy plants have highly response to changed price in the market. Price influences farmers to increase supply for bioenergy in the domestic market and global market. Thus, substituted agricultural products for energy become a new opportunity for Thai agricultural market.

Another factor influences the demand for exporting in climate change during the decade. There are phenomena around the world, flooding is a major factor to decline agricultural products. Thailand has faced to this problem in some year also the neighbor countries such as Vietnam, Lao, the Philippines, and China. Forecasting of climate change is necessary. Farmer should manage the production to support the food security, which is a major of the global market.

Vietnam, Lao, the Philippines, China, and Thailand are top exporting agricultural countries. These countries has market share in the global market. According to the weather or other individual country's problem, other countries would have opportunity to increase market share. Thailand has opportunity to increase some agricultural products in the world market thus this study will report the analysis of the demand elastic for some agricultural products that will increased market share in the world market. Also, this study will suggest the new or alternative policies to support agricultural products (FAO, The Agricultural Product 19972007).

\section{Conclusion}

This paper analyzes the demand for major agricultural products; palm, rubber, cassava, rice, and sugar by using Almost Ideal Demand System (AIDS) model. The study shows the demand for rubber export is not affected from this price also rice. Another result shows that the demand for palm, cassava, and sugar response with price.

Rubber and rice are major export of Thailand, which palm, cassava, and sugar have opportunity to become major export agriculture of Thailand. These three products are highly response with changed price; these encourage farmers to increase supply. It should be the new products also market for agricultural products of Thailand.

The results also show that the total export increase demand for rubber and rice because of these are useful for the world living. In the opposite, total export valued of palm, cassava, and sugar is increasing in demand when market price increases. This indicates that palm, cassava, and sugar are sensitive with price and should be benefits for Thai farmers. Sometime, the agricultural products of Thailand is destroyed www.journals.cz/ by climate disaster thus Thailand should have technology to forecast climate also planning for oversupply and over demand that always happen in agricultural countries also encourage increasing production of energy plants.

In some years, Thailand receives the opportunity to increase GDP by this global climate changing. This will not expect and could not use to predict GDP of Thailand. Therefore, Thailand should have the sustainable policy to support the agricultural product market to increase living standard of the country.

According to the study, Thailand is named as agricultural country. Rice and rubber is a major exporting product. But the agricultural community include farmer has life quality depends upon the environmental change. It does not depend upon the stability in economy and quality of life also technology. Palm, cassava, and sugar should increase benefits in the farmers' society.

\section{REFERENCES}

1. Alston, J.M., K.A. Foster, and R.D. Greene. "Estimating Elasticity with the linear Approximate Almost Ideal Demand System: Some Monte Carlo Results." The review of Economics and Statistics (1994): 351-355.

2. Barten, A. P. "The systems of consumer Demand Function Approach: A Review." Econometrica. 45(1977): 23-48.

3. Brown, M.G. "Impact of income on Price and Income Responses in the Differential Demand system." Journal of Agricultural and Applied Economics, 40:2 (2008): 593-608.

4. Deaton, A., and J. Muellbauer "An Almost Ideal Demand System." The American Economic Review 70 (1980): 312-326.

5. Dhar, T., and J. D. Foltz. "Milk by Other Name Consumer Benefits From Labeled Milk." American Journal of Agricultural Economics 87 (2005): 217-228.

6. Dimitri, C., and C. Green. Recent Growth Patterns in the US Organic Foods Market. Economic Research Service, U.S. Department of agriculture, June 2000.

7. Dimitri, C., C. Green., and C. Greene. Organic Marketing Features Fresh Foods and Direct Exchange. Food Review, January- April 2001.

8. Eales, J. S., and L. J. Unnevehr. "Simultaneity and Structural Change in U.S. Meat Demand." American Journal of Agricultural Economics 75 (1993): 259-268.

9. Eales, J. S., and L. J. Unnevehr. "Demand for Beef and Chicken Products: Saparability and Structural Change." American Journal of Agricultural Economics (1988): 521-532.

10. FAO, Agricultural products 1997-2007

11. Glaser, L. K., and G.D. Thompson. "Demand for Organic and Conventional Beverage Milk." Paper presented at the Western Agricultural Economics Association Annual Meeting, Vancouver, British Columbia, 29 June-1 July, 2000.

12. Griffiths, W. E., R. C. Hill, and G. G. Judge. Learning and Practing Econometrics, John Wiley \& Sons, Inc., 1992.

13. Jabarin, A. S. "Estimation of meat demand system in Jordan: an almost ideal demand system" International Journal of Consumer Studies 29:3 (2005): 232-238.

14. Le, C. Q. "An Empirical Study of Food Demand in Vietnam" ASEAN Economic Bulletin 25:3(2008): 283-292.

15. Moschini, G. "Units of Measurement and the Stone Index in Demand System Estimation." American Journal of Agricultural Economics 77 (1995): 63-68.

16. Pacific food system outlook, 2009-2010.

17. The office of National Economic and Social Development Broad, Thailand, $2002-2010$.

18. The office of Agricultural Economics, Ministry of Agricultural and Cooperative, Thailand, $1998-2010$.

19. Rangkakulnuwat, P. "The analysis of Demand System for agricultural Export Products in Thailand Using LAIDS" NIDA Development Journal 48(3) (2008) 48-61.

20. Sheng, T. Y., M. N. Shamsudin, and et. al. "A Complete Demand System of Food in Malaysia" The Icfai University Journal of Agricultural Economics 5 : 3 (2008): 17- 29.

21. Sakong, Y. and Hayes, D. J., "Testing the Stability of Preferences: A Nonparametric Approach

22. American Journal of Agriculture Economic 75 (1993): 269-277. 